\title{
Architecture_MPS
}

Article

\section{Accessing the Neighbourhood: Built Environment Performance for People with Disability}

\author{
Mary Ann Jackson 1,2 \\ ${ }^{1}$ PhD candidate, Swinburne University of Technology, Melbourne, Australia \\ ${ }^{2}$ Director, Visionary Design Development PTY LTD, Melbourne, Australia
}

Guest Editor: Glyn Everett, University of the West of England, UK

How to Cite: Jackson, M.A. 'Accessing the Neighbourhood: Built Environment Performance for People with Disability.' Architecture_MPS 16, 1 (2019): 4.

DOI: https://doi.org/10.14324/111.444.amps.2019v16i1.004.

Submission date: 25 September 2018; Acceptance date: 21 April 2019; Publication date: 1 December 2019

\section{Peer review:}

This article has been peer reviewed through the journal's standard double blind peer-review, where both the reviewers and authors are anonymised during review.

\section{Copyright:}

(C) 2019, Mary Ann Jackson. This is an open access article distributed under the terms of the Creative Commons Attribution License (CC BY) 4.0 https://creativecommons.org/licenses/by/4.0/, which permits unrestricted use, distribution and reproduction in any medium, provided the original author and source are credited $\bullet$ DOI: https://doi.org/10.14324/111.444.amps.2019v16i1.004.

\section{Open access:}

Architecture_MPS is a peer-reviewed open access journal.

\begin{abstract}
In the face of rapid urbanisation, increasing diversity of the human condition, ageing populations, failing infrastructure, and mounting evidence that the built environment affects health and well-being, the existing built environment still fails to meet the needs of people with disability. Nevertheless, in something of a parallel universe, improving built environment 'sustainability' performance, via measurement, receives much contemporary attention, and analysing the built environment at micro-scale (buildings), meso-scale (neighbourhood) and macro-scale (city-wide) is undertaken from various multidisciplinary perspectives. But, although built environment performance is already measured in many ways, and community inclusion is considered essential for health and well-being, accessibility performance for people with disability, at neighbourhood scale, is rarely considered. The institutional and medical models of disability help explain the inaccessibility of the existing built environment. On the other hand, the social and human rights models of disability offer insight into improving the accessibility of the existing built environment for people with disability. However, 'disability' and
\end{abstract}


'built environment' tend not to mix. People with disability continue to experience lack of meaningful involvement in research, participation in decision-making, partnership equality, and direct influence over policy, with the built environment arena increasingly becoming a private-sector activity. The actors involved, however, have little understanding of either the accessibility needs of people with disability, or the inaccessibility, particularly at neighbourhood scale, of the existing built environment. It is in this context that this paper explores the design, planning and politics of an inaccessible built environment, concluding that assessing the built environment accessibility performance for people with disability, at neighbourhood scale, is an essential component in the process of built environment accessibility improvement. Requiring collaboration between the built environment and disability knowledge domains, a new tool measuring neighbourhood accessibility, the Universal Mobility Index (UMI), has emerged and is undergoing further development.

Keywords: built environment performance; built environment accessibility; people with disability; neighbourhood; Universal Mobility Index (UMI); design; planning; politics 


\section{Introduction}

Worldwide, as well as in Australia, many challenges to achieving a sustainable, resilient built environment have been identified, including multidimensional resourcing constraints, rapid urbanisation, failing infrastructure and socio-demographic change. ${ }^{1}$ Populations are known to be ageing, human diversity is increasingly recognised, and evidence that the built environment affects health and well-being is mounting. ${ }^{2}$ The 'neighbourhood' as a key spatial and social construct, and focus of policy and practice, has received attention across many fields, for example planning, community development, health and sustainability. ${ }^{3}$ Obviously, the neighbourhood built environment is used by people with disability. Nonetheless, the accessibility performance of the existing built environment, particularly at neighbourhood scale, continues to fail people with disability. ${ }^{4}$

However, in something of a parallel universe, much built environment assessment research is being undertaken. Many city-enhancement movements, sustainability indicators and built environment performance measures already exist. Improving built environment 'sustainability' performance, via measurement, receives much contemporary attention. ${ }^{5}$ Within the associated bodies of literature, the need to research, critically appraise and measure the existing built environment is well established. Why, then, is built environment accessibility performance at neighbourhood scale for people with disability so rarely considered?

This paper endeavours to respond to this question. First, a brief review of building performance measures, urban realm assessment, and interdisciplinary health-built environment analysis is presented. Second, the lack of engagement with people with disability in relation to accessing neighbourhoods, and the resultant poor built environment accessibility performance, are discussed under the headings 'design', 'planning' and 'politics'. Last, the case for assessing neighbourhood accessibility performance, an essential component in the process of built environment accessibility improvement, is put forward.

\section{Built Environment Performance Measures}

The performance of residential and commercial buildings and/or their components is already measured in a myriad ways, in Australia and elsewhere. Such tools range from measuring the performance of particular aspects of singular building componentry, including appliances, through to comprehensive investigations of total building systems, albeit from specific perspectives. Furthermore, measurement systems have been in place for decades. In Australia, major household appliances have been star-rated since the mid-1980s. ${ }^{6}$ More recently, in September 2018, and aimed at global scale, the Net Zero Carbon Buildings Commitment officially launched. ${ }^{7}$ Backed by the World Green Building Council (WGBC), the project requires signatories to instigate national net zero carbon rating tools and certification schemes by 2030 and commit to all (100 per cent) buildings within their portfolios being net zero carbon by $2050{ }^{8}$

Energy rating systems aimed at improving energy efficiency and/or reducing operating costs within buildings started gaining traction worldwide in the early 1990s. A unifying feature of these systems is benchmarking and rating, permitting succinctly communicated comparison across differing installations and (numerical) 'incentives' to do better. Some common examples of such systems are noted in Table 1. Current iterations of such tools are invariably more sophisticated (technical) and/or comprehensive (sustainability-oriented) than when first released.

Table 1 Rating systems examples.

\begin{tabular}{|c|c|c|c|c|}
\hline Acronym & Name/Organisation & $\begin{array}{c}\text { Description (Refer to Endnotes for } \\
\text { Website/Control Entity/Further Information) }\end{array}$ & $\begin{array}{l}\text { Country of } \\
\text { Origin }\end{array}$ & Year \\
\hline WERS & $\begin{array}{l}\text { Window Energy Rating } \\
\text { System }\end{array}$ & $\begin{array}{l}\text { Rates and labels windows for annual energy impact } \\
\text { on house, throughout Australia. }{ }^{9}\end{array}$ & Australia & 1995 \\
\hline WELS & $\begin{array}{l}\text { Water Efficiency Labelling } \\
\text { and Standards }\end{array}$ & $\begin{array}{l}\text { WELS Standard and scheme powers and functions } \\
\text { are legislated. }{ }^{10}\end{array}$ & Australia & 2006 \\
\hline
\end{tabular}


Table 1 Cont.

\begin{tabular}{|c|c|c|c|c|}
\hline Acronym & Name/Organisation & $\begin{array}{c}\text { Description (Refer to Endnotes for } \\
\text { Website/Control Entity/Further Information) }\end{array}$ & $\begin{array}{l}\text { Country of } \\
\text { Origin }\end{array}$ & Year \\
\hline NABERS & $\begin{array}{l}\text { National Australian Built } \\
\text { Environment Rating } \\
\text { System }\end{array}$ & $\begin{array}{l}\text { Rates energy efficiency, water usage, waste } \\
\text { management, and indoor environment quality of, } \\
\text { mainly, commercial buildings and tenancies. }{ }^{12}\end{array}$ & Australia & 1998 \\
\hline Green Star & $\begin{array}{l}\text { Green Building Council } \\
\text { Australia }\end{array}$ & $\begin{array}{l}\text { Multiple tools covering homes, various commercial } \\
\text { building typologies, tenancies and communities. }{ }^{13}\end{array}$ & Australia & 2003 \\
\hline iPHA & $\begin{array}{l}\text { The International Passive } \\
\text { House Association }\end{array}$ & $\begin{array}{l}\text { Research on, and development of, construction } \\
\text { concepts, building components, planning tools and } \\
\text { quality assurance for highly energy } \\
\text { efficient buildings. }{ }^{14}\end{array}$ & Germany & 1990 \\
\hline LEED & $\begin{array}{l}\text { Leadership in Energy and } \\
\text { Environmental Design }\end{array}$ & $\begin{array}{l}\text { For all building types, e.g. hospitals, data centres, } \\
\text { historic buildings, and in design. }{ }^{15}\end{array}$ & USA & 1993 \\
\hline BREEAM & $\begin{array}{l}\text { Building Research } \\
\text { Establishment } \\
\text { Environmental } \\
\text { Assessment Method }\end{array}$ & $\begin{array}{l}\text { Sustainability assessment across built environment } \\
\text { life cycle, i.e. new, in-use and refurbishment. }{ }^{16}\end{array}$ & UK & 1990 \\
\hline BEST & $\begin{array}{l}\text { Built Environment } \\
\text { Sustainability Tool }\end{array}$ & $\begin{array}{l}\text { Purports to support integration of sustainability into } \\
\text { urban built environments. }{ }^{7}\end{array}$ & $\begin{array}{l}\text { South } \\
\text { Africa }\end{array}$ & 2013 \\
\hline SB Tool & $\begin{array}{l}\text { International Initiative for } \\
\text { a Sustainable Built } \\
\text { Environment }\end{array}$ & $\begin{array}{l}\text { Generic framework for rating sustainable } \\
\text { performance of buildings and projects. }{ }^{18}\end{array}$ & Europe & 2007 \\
\hline CASBEE & $\begin{array}{l}\text { Comprehensive } \\
\text { Assessment System for } \\
\text { Built Environment } \\
\text { Efficiency }\end{array}$ & $\begin{array}{l}\text { Assessment tools tailored to different scales: } \\
\text { construction (houses and buildings), urban (town } \\
\text { development) and city management. }{ }^{19}\end{array}$ & Japan & 2001 \\
\hline G-SEED & $\begin{array}{l}\text { Green Standard for Energy } \\
\text { and Environmental Design }\end{array}$ & $\begin{array}{l}\text { Korea-specific, comprehensive system similar } \\
\text { to LEED. }{ }^{20}\end{array}$ & Korea & 2002 \\
\hline LOTUS & $\begin{array}{l}\text { Vietnam Green Building } \\
\text { Council }\end{array}$ & $\begin{array}{l}\text { Framework for building designers to benchmark } \\
\text { environmental performance. } .^{21}\end{array}$ & Vietnam & 2005 \\
\hline GRIHA & $\begin{array}{l}\text { Green Rating for Integrated } \\
\text { Habitat Assessment }\end{array}$ & $\begin{array}{l}\text { Assesses the performance of buildings against } \\
\text { certain nationally acceptable benchmarks. }{ }^{22}\end{array}$ & India & 2007 \\
\hline
\end{tabular}

As alluded to above, the concept of 'energy efficient buildings' has morphed through 'environmentally green building' and has, more recently, embraced broader readings of 'sustainability', including a greater recognition that people inhabit buildings. Developing from a theoretical idea that emerged in the mid-1990s, the Living Building Challenge (LBC, the Challenge) was codified and launched in late 2006. ${ }^{23}$ The Challenge - with its seven performance areas of Place, Equity, Water, Beauty, Materials, Health + Happiness, and Energy - is considered one of the most onerous, multidimensional building performance tools currently in use. ${ }^{24}$ Life cycle assessment (LCA) originated out of project-based 1960s and 1970s energy analysis, moved through policy-based applications in the 1990s, and was mainly concerned with environmental impacts in the 2000s ${ }^{25}$ LCA is, however, ever-divergent and evolving; a current focus includes life cycle sustainability analysis (LCSA) covering the people (social), planet (environmental) and prosperity (economic) dimensions of sustainability. ${ }^{26}$ Although early on, in the early 1990s, indoor air quality (IAQ) was predominantly a concern of heating, refrigerating and air-conditioning engineers (HRAEs), the field has subsequently broadened out to consider indoor environment more holistically. Now, using standards and methodologies such as the British Standard BS ISO 17772, Indian Standard ISHRAE Standard 10001: 2016 - Indoor Environmental Quality Standard, and the Building Occupants Survey System Australia (BOSSA), indoor environmental quality (IEQ) is assessed in terms of thermal comfort/temperature, fresh air/indoor air quality, daylight/lighting/lighting comfort, and acoustics/acoustic comfort. ${ }^{27}$ Further, building occupant well-being is now studied through methodologies such as the WELL Building Standard. ${ }^{28}$ Grouped under its eleven 'concepts' of: Air, Water, Nourishment, Light, Movement, Thermal Comfort, Sound, Materials, Mind, Community and Innovation, the ambit of the 
WELL Building Standard (v.2 pilot) is wide. ${ }^{29}$ Most unusually, but very encouragingly, disability is acknowledged, universal design (UD) is referenced, and accessibility requirements are noted. ${ }^{30}$

Formal assessment via any of the tools mentioned above requires significant financial outlay as assessment is, almost without exception, undertaken by accredited experts using specialised computer software. The shortcomings of 'one-off' sustainability assessment tools, and the mismatch between 'as designed' ratings and 'as built' performance, is coming under increasing scrutiny; 'set and forget' is insufficient - evaluation of actual performance, and ongoing monitoring, is required. ${ }^{31}$ Enriched post-occupancy data collection, more in-depth behavioural studies, and more sophisticated monitoring activities, enhanced by ever-developing computerised analysis systems, are anticipated to improve built environment-human interaction sustainability outcomes. ${ }^{32}$ Building accessibility, however, is usually 'compliance' access-audited against enigmatic legislation, and presented in esoteric spreadsheet format, without any overarching narrative outlining the significance of the individually itemised entries. ${ }^{33}$ Conventional access auditing, also usually undertaken by accredited experts for a substantial fee, also does not accommodate monitoring, or the collection of post-investigation user satisfaction data, or sophistication of computerised analysis systems, particularly those involving GIS.

Urban realm measurement interests are wide-ranging. Assessing and/or ranking city-scale sustainability, resilience, liveability, smartness and more, is now well-entrenched (see, for example, EIU's Livable Cities, Mercer's Quality of Living, AT Kearney's Global Cities Index, Smart Cities, Resilient Cities, Healthy Cities, and Age-Friendly Cities). Non-standardised evaluation methodologies are, however, cited as a problem. ${ }^{34}$ Nevertheless, irrespective of specific methodology, the core beliefs of resilient cities evaluation, for example, are: first, that to become more resilient, improvement is needed; second, that existing conditions measurement, via indicators, is an essential precursor to improvement; and third, that cross-sectorial and interdisciplinary collaboration is required ${ }^{35}$ Healthy cities evaluation (why, what, for who, by who and how) is also an ongoing thorny issue, but comprehensive problem mapping at the outset leads to enhanced project and participation outcomes. ${ }^{36}$ Ethical cities measurement processes are still embryonic, but both 'objective' quantifiable measures and more qualitative measures involving engagement, judgement and discussion have their valuable places in measurement. ${ }^{37}$ Therefore, although multiplicity of assessment methodologies is questioned, measurement and collaboration across multiple domains is essential. Disturbingly, however, the need for 'accessibility in the built environment' improvement for people with disability is rarely mentioned directly, if at all.

From at least the late 1970s, improving transport infrastructure and public transport has been on the research agenda. Systematically investigating existing physical conditions and policy contexts, development of evaluation methodologies including indices, interdisciplinary collaboration, and stakeholder engagement at local citizen level are all common components of road re/construction, road safety auditing, 'safe system' traffic safety, 'shared space' design, 'roads as places', and mobility. ${ }^{38}$ In the public transport field, although motivations for desired improvements are manifold, and initiating entities across multiple modes diverse, common tasks include acquiring quantitative data; ascertaining physical, disciplinary and political interconnections; and understanding the existing condition of public transport built assets. ${ }^{39}$ Again, a worryingly common feature of these endeavours is the lack of inclusion of the lived experience of people with disabilities.

Much mapping and modelling, including computer-generated spatial investigations using GIS software, has been undertaken throughout the world. ${ }^{40}$ Sidewalk details, however, are still commonly missing from GIS datasets. ${ }^{41}$ Modelling for fire engineering (in dense built-up areas) has been developed. ${ }^{42}$ Sustainable mobility has been indexed. ${ }^{43}$ Investigating walkability, measuring urban form complexity, assessing sustainable urban design, and examining crash severity and streetscape design, are common, contemporary, areas of in-depth built environment performance research occurring at neighbourhood scale. ${ }^{44}$ Improving existing roads, improving road safety, and designing shared pedestrian-vehicle space routinely involves systematically investigating existing physical conditions, evaluating policy frameworks, and community engagement. ${ }^{45}$ Nevertheless, the urban realm accessibility needs of people with disabilities are rarely considered, and their direct input is rarely sought. 
Within the interdisciplinary health-built environment field, scrutinising the built environment at micro-scale (buildings), meso-scale (neighbourhood) and macro-scale (city-wide) is also well established. Often undertaken from multidisciplinary perspectives, there has been much analysis, particularly within the last decade, involving researching, imaging, recording and measuring the interaction between people and their environments, with a view, for example, to increasing physical activity, obtaining insights into older adults' mobility and well-being, enhancing active travel, reducing negative impacts on health at home, and increasing positive impacts on health at the community level. ${ }^{46}$ The need to view the 'problem' at the scale of the user, and from a user-centred vantage point is acknowledged. ${ }^{47}$ But, Appleyard, for example, continues the entrenched tradition of highly technical transport-land use evaluation undertaken by experts only; no lived experience and/or community member input is sought, and no concern for the specific travel needs of people with disability is expressed. The key recommendations of health-built environment projects for future research often include focusing on changing existing environments and pursuing interdisciplinary understanding. ${ }^{48}$ Nevertheless, although terminology such as 'social inclusion for all' (or similar) is becoming more common, the need for improving 'accessibility in the built environment', for people with disability, is still rarely, if at all, directly mentioned.

\section{Accessing the Neighbourhood?}

\section{Design}

Existing built environment inaccessibility can be explained, partly, by the central tenets of historical disability models, such as the charity (institutional) and medical models of disability. ${ }^{49}$ Under these models, the public profile of people with disabilities was rendered virtually non-existent. ${ }^{50}$ While outwardly signifying care and protection of the vulnerable other, the charity model, and the similar religious and moral disability models, point to the desire to control, via segregation, 'deviant members' of society. ${ }^{51}$ A core response was the construction of institutions. Therefore, in the context of the built environment, the charity model of disability effectively translates to 'we don't have to worry about them, they are put away' in institutions. ${ }^{52}$ Often large and imposing, with cavernous dormitories and sited within extensive grounds away from town centres, asylums, a common landmark of the late 1800s and early 1900s in Australia, the UK and the USA, are a clear built-form manifestation of the institutional nature of the charity model of disability. ${ }^{53}$ Imrie observed that 'western cities are characterized by a design apartheid where building form and design are inscribed with the values of an "able-bodied" society" 54 - a consequence of the charity model's invisible segregation of people with disability.

Central tenets of the medical model of disability are that, first, a person's 'impairment' can be diagnosed, cured, or at least rehabilitated, by modern medicine and/or medical technology, and, second, that such interventions will be provided by all-knowing professionals. ${ }^{55}$ The medical model, in a health context, is based on classifying levels of deviance or deficiency compared to a supposedly normative state. ${ }^{56}$ Similar models, such as personal tragedy model, individual model and rehabilitation model, often used interchangeably, point to the individualised emphasis of the medical model. Such ideology tends to lead to the (unacknowledged) belief among built environment practitioners that the built environment accessibility needs of people with disabilities will be resolved by individual provision of personalised medical intervention and/or assistive technology. For built environment practitioners, therefore, the medical model of disability effectively translates to 'we don't have to worry about them, they will be fixed' or, again, institutionalised ${ }^{57} \mathrm{~A}$ crucial consequence of the once pervasive ideology of institutionalisation, which reached its peak under the medical model, is that much existing built environment, particularly within the public realm, is inaccessible for people with disability. ${ }^{58}$

Engendered by the low public profile of people with disabilities, conformist societal attitudes, design precedents, weak legislation, and poor understanding of the built environment accessibility needs of people with disability, a significant extent of the existing built environment and public transport infrastructure has been designed within a paradigm of a charity/medical model of disability, albeit unconsciously. Another reading of exclusionist design thinking is provided by Finkelstein and Hunt; their social relational theory concludes that social exclusion of people with disability was an outcome 'of the materialist landscape of the industrial era' rendering them economically unviable. ${ }^{59}$ Viewed through such a lens, design of 
factories and workplaces, schools, public transport systems and infrastructure was heavily influenced by the attitudes of the designers' clientele. In contrast, well-known contemporary disability models, such as the social and human rights models of disability, offer insight into the imperative of improving the accessibility of the existing built environment. ${ }^{60}$

The social model of disability was developed in the early 1980s by Mike Oliver, a British academic and disability activist. As explained by the social model, disability arises from barriers within 'an oppressive and discriminating society', rather than from impairment per se. ${ }^{61}$ In a challenge to the medical model, the onus of response is shifted to society to dismantle barriers that construct disability. ${ }^{62}$ The social model of disability therefore recognises that disability is not a pre-existing, independent, condition - the built environment is a disabling instrument in itself, that is, the nature and experience of disability is directly linked to the built environment. ${ }^{63}$

New ways of thinking had also extended to built form. Internationally, postmodernist architecture had started to emerge in the 1960s. However, in the 1980s, the Australian, popular version, was rarely manifested in more than facade form and decoration; little attention was paid to postmodernism's underlying hallmark concerns of diversity and discrimination. Therefore, urban layouts and building design in Australia remained largely untouched by the concerns of either postmodern social theorists or proponents of the social model of disability, thus remaining as inaccessible as ever.

The currently unfolding human rights model of disability did not spontaneously appear, but rather evolved within a continuum of rights-based thinking. ${ }^{64}$ In response to an emphasis on rights and deinstitutionalisation, disability research and activism work in the USA precipitated the emergence of the independent living movement in Berkeley, California in the early 1970s. ${ }^{65}$ On the other hand, Schindler (2015) highlights the discriminatory power, through design and planning mechanisms, that the built environment has had, and continues to have, over people's lives. Central to the human rights model is that all people have rights, including that of built environment access. ${ }^{66}$ The human rights model, empowered by the United Nations Convention on Rights of Persons with Disabilities (UNCRPD), specifically draws attention to the wide-ranging nature of the built environment, for example, housing, public buildings, transport and social/cultural/recreational locations. ${ }^{67}$

In discussing the development towards the UNCRPD, Bruce restates the views of prominent disability studies writers (for example, Zola, Oliver and Hahn) in explicitly problematising inaccessible built environments for people with disability. ${ }^{68}$ Theresia Degener characterises the inaccessibility of the built environment as a human rights problem, suggesting that disability studies has moved beyond the debate of medical versus social models of disability into a new era: a human rights model of disability era as epitomised by the UNCRPD. ${ }^{69}$ Notions of spatial inclusion at community level are embedded in the UNCRPD and, as evidenced by Preamble and Article content, the way people are supported to interact with their (neighbourhood) environment is considered crucial. ${ }^{70}$ The UNCRPD/human rights model of disability presages more obviously defined, and compliance-enforceable, built environment accessibility legislation - the prescriptive Americans with Disabilities Act (ADA, USDoJ 2017), for example, rather than the performance-based Australian Disability Discrimination Act. ${ }^{71}$

From my 'accessibility in the built environment' specialist perspective, I believe that understanding the above concepts is invaluable. Improving built environment accessibility is, however, compromised by the lack of understanding of disability issues, including disability models, by built environment practitioners, and the lack of direct engagement with people with disability and the lack of content in curricula. ${ }^{72}$ Architects, planners, builders and construction engineers, in Melbourne at least, have virtually no exposure to universal design (UD) at trade, undergraduate, postgraduate or continuing professional education levels. ${ }^{73}$ In 2015, in Australia, across urban design, planning and architecture, no major built environment design programme at undergraduate or postgraduate level contained universal design, designing for disability, inclusive design, people-centred design or the like as a core course. ${ }^{74}$ In 2016-18, while technical tutor at a leading Melbourne-based university, I found that only 1-3 students in each design studio group of around 16 postgraduates had previous exposure to disability-related teaching content.

Furthermore, built environment design practitioners - architects, for example - are programmed through entrenched educational systems to view the built environment as a 'problem' requiring 'solving' ${ }^{75}$ 
However, conventional training and conventional, isolationist, built environment problem-solving approaches leave built environment design practitioners ill-equipped for an increasingly complex, interdisciplinary, modern world, particularly a world of urbanised, ageing populations and diverse people with disability. ${ }^{76}$

\section{Planning}

Many people with disability across regions as diverse in resources, geography, politics and culture as the UK, New Zealand, Australia, Canada, the USA, continental Europe, Scandinavia, Asia, the Pacific Islands, the African continent and Latin America, find their everyday environments a daily, overwhelming struggle. ${ }^{77}$ Common themes are very obvious: social inclusion is stymied by the inability to navigate broken travel chains; built environment elements of greatest concern are housing, the public realm pedestrian environment, and public transport; lack of enforcement of existing legislation is a very significant problem; and inconsistent and/or misinterpretation of existing legislation is also problematic. ${ }^{78}$ Despite all this, accessibility for people with disability in the urban realm, a realm intimately related to 'planning', appears to be a built environment performance measure blind spot.

Relationships between physical locations and design quality, individual buildings and the neighbourhood, conventional planning and modern urban form, global and local contexts, and streetscape design and traffic management are complex. ${ }^{79}$ Nonetheless, sustainability measurement tools at neighbourhood scale, interdisciplinary sustainability assessment at various scales, and weighted indicators for the purpose of 'sustainability' evaluation, are now ubiquitous. ${ }^{80}$ Ewing, Handy, Brownson, Clemente and Winston (2006) argue that, by way of systemised measurement, quantification of qualitative urban design qualities is achievable. ${ }^{81}$ Sipe, Mayere-Donehue and Dedkorkut (2011) emphasise the educational value, for both professionals and academics, of measuring urban form via international comparative analyses. ${ }^{82}$ A common thread running through the literature, however, is the need to critically appraise and measure the existing urban environment. Assessment of urban design qualities and landscape character can, with the appropriate checks and balances, be undertaken by laypeople. ${ }^{83}$ Therefore non-expert local citizens directly assessing existing conditions for the purposes of improving future outcomes is not a weird idea. But embedding people with disability in assessment processes is, disturbingly, still novel.

Improving urban environments via placemaking is now well established in the urban planning lexicon. Placemaking is based on the idea that 'places' are more than mere physical spaces, and, as such, can be considered in planning terms as a kind of 'performance' enhancement. Professional disciplines such as landscape architecture and urban design are often intimately involved in the process of placemaking through urban realm planning and design. Local government authorities, in Melbourne and elsewhere, often have 'place managers' and/or placemaking teams allocated to particular geographical precincts. Early placemaking proponents were somewhat evangelical. The Project for Public Spaces and Metropolitan Planning Council (2008) claimed, for example, that placemaking 'has the potential to be one of the most transformative ideas of this century'. ${ }^{84}$ Albeit not necessarily neighbourhood-scale dependent, the intentionally interdisciplinary notion of placemaking is heavily reliant on the concept of 'the neighbourhood'. ${ }^{85}$ A currently unfolding iteration of placemaking is 'placeshaping' ${ }^{86}$ Pugalis posits that placeshaping proponents are less enthusiastic about the end-product focus and deterministic nature of placemaking, believing that the process-focused placeshaping approach will yield superior place quality, 'a constituent factor in the shaping of places that enriches social experiences and economic interactions'. ${ }^{87}$

Although application may vary, placemaking principles commonly considered essential worldwide include meaningful community stakeholder engagement and existing conditions evaluation (see, for example, Placemaking Chicago: http://www.placemakingchicago.com/). Placeshaping, however, appears to be somewhat in danger of being hijacked by city shaping, (that is, production of iconic infrastructure invariably undertaken by the big end of town), with a resultant lack of attention to grass-roots, social inclusion planning for people with disability. Nonetheless, infrastructure conventionally considered as vehicular transport infrastructure - roads, for example - is under the placemaking evaluation spotlight. ${ }^{88}$ If roads are to be considered places, then it is certainly timely to gain deeper understanding of people 
with disabilities' current lived experience of both the iconically planned and grass-roots unplanned infrastructure environment.

Social inclusion at community level is considered essential for health and well-being. ${ }^{89}$ But people with disability 'can't get there, can't get in, can't get it' ${ }^{90}$ From a policy perspective, the neighbourhood is of vital importance in influencing children's physical activity levels and older persons' physical activity, health and well-being. ${ }^{91}$ Poor pedestrian infrastructure limits older persons' physical activity. ${ }^{92}$ Independent living in 'ordinary' community settings is obviously stymied if the neighbourhood pedestrian environment is inaccessible. Disadvantaged communities tend to exhibit poorer outcomes across a range of health and well-being measures, including physical activity and social exclusion. ${ }^{93}$ However, the relationship between neighbourhood factors and disability is little researched. ${ }^{94}$

\section{Politics}

Regarding the built environment, people with disability continue to experience lack of meaningful involvement in research, participation in decision-making, partnership equality and direct influence over policy. ${ }^{95}$ In response, people with disability often form their own, grass-roots, specific-interest, 'self-advocacy' groups. ${ }^{96}$ However, such groups tend to have limited impact, as they rarely have sufficient resources to engage in systemic advocacy, an advocacy model considered more effective for policy change. ${ }^{97}$ On the other hand, well-resourced, 'healthy environments' advocacy tends to encompass improving public transport service levels, increasing active transport, making neighbourhoods walkable, communities healthy, ageing actively, and the like, with scant reference to people with disability. ${ }^{98}$ 'Human interaction with the built environment' research continues to exclude people with disability through design limitation and/or intention. ${ }^{99}$ Across Europe, disabled people's organisations (DPOs) believe that people with disabilities' lived experience of transport, housing, ageing, reasonable accommodations (in education and employment), workplace design and vision impairment is little understood and requires multidisciplinary research involving architecture and design. ${ }^{100}$ The built environment is significantly under-represented within Australia's disability research base. ${ }^{101}$

Emerging partnership concepts such as 'co-production' and 'co-design' are gaining traction in the public service delivery/social policy/disability studies arena. ${ }^{102}$ Built environment professionals have, by and large, not heard of such things. Built environment researchers and professionals have not paid much attention to people with disability, nor to their physical, sensory, societal or political interactions with the built environment. ${ }^{103}$ Furthermore, advocacy for built environment accessibility, usually, merely calls for compliance with relevant anti-discrimination and construction legislation, which, invariably, do not mention 'the neighbourhood' at all.

People with disabilities' right to inclusion is, at face value, enshrined in multiple layers of legislation, including the internationally recognised UNCRPD. By, in effect, requiring all of the built environment to be accessible, the UNCRPD is groundbreaking, but there are several layers of procedure between adoption and legislative 'standing' within a country. Although Australia has not specifically incorporated the UNCRPD into domestic law, ratification imposes inherent obligations. ${ }^{104}$ Within Australia, however, most built environment practitioners are not familiar with the UNCRPD and, worldwide, people with disability continue to experience significant difficulty in accessing the built environment, particularly at neighbourhood scale. ${ }^{105}$

Political direction, societal norms and entrenched ways of working inform governance structures, which are then reflected in regulatory methodologies. ${ }^{106}$ In Australia, in built environment longevity terms, built environment accessibility legislation is relatively recent. Historically, various state-based building regulations generally contained some provision for 'disabled access'. However, the DDA was not enacted until 1992, the Building Code of Australia (BCA, (ABCB 2016)) was not fully adopted nationwide until 1998. Braille and tactile signage requirements were not included in the BCA until Amendment 10 in 2002, and the (Australian) Disability (Access to Premises - Buildings) Standards 2010 (Premises Standards, (Australian Government 2010)) was not in force until 2011!

Furthermore, built environment legislation is opaque. ${ }^{107}$ As $\mathrm{I}^{108}$ have discussed previously, Australia's complaints-based DDA provides a broad-brush overarching framework, but makes scant direct 
reference to the built environment. The (Australian) Disability Standards for Education 2005 (Education Standards) are generally ignored by built environment practitioners and the Disability Standards for Accessible Public Transport 2002 (Transport Standards) and Disability (Access to Premises - Buildings) Standards 2010 (Premises Standards, Australian Government 2010) are incomprehensible to those without sufficient background technical knowledge and access to all referenced documents, the latter not being freely available. Deemed-to-satisfy provisions, in both the Premises Standards and the Building Code of Australia (BCA), are not prescriptive; satisfying the Performance Requirements is the legislative requirement. Significant portions of buildings, for example, fit-out, fixtures and fittings, are not directly covered in deemed-to-satisfy provisions, which mainly focus on wheelchair-accessible paths of travel and toilets. BCA Parts concerning 'accessibility' do not reference either the DDA, or Disability Standards. The BCA and the Premises Standards do not cover the public realm pedestrian environment nor most private dwellings, categories of built form spatially comprising most of the built environment and two of the three most common areas of built environment accessibility distress for people with disability. ${ }^{109}$ As a result, within Australia, built environment practitioners' understanding of accessibility is limited, tending to devolve into a checklist response to BCA Part D3 clauses.

As noted in this paper and elsewhere, 'disability' and 'built environment' tend not to mix. ${ }^{110}$ Built environment accessibility policy is undeveloped, and built environment accessibility legislation is object-centred, implementation-focused, and taken as fact. ${ }^{111}$ In contrast, as indicated by my current $\mathrm{PhD}$ studies, disability legislation and policy tends to be person-centred, policy reasoning explained, and, essentially, a public sector activity. Creating and delivering built environment form is, conversely, increasingly a private-sector activity. ${ }^{12}$ The actors involved, however, have little understanding of either the accessibility needs of people with disability, or the inaccessibility, particularly at neighbourhood scale, of the existing built environment.

\section{Assessing Neighbourhood Accessibility Performance: Measure}

Empirical measurement of the existing built environment, particularly at neighbourhood scale, is lacking. ${ }^{113}$ As I ${ }^{114}$ have previously discussed, ongoing development of publicly available access auditing tools is occurring in the USA. Assessment using such tools is, however, invariably compliance-based, in checklist format, and not an easily communicable measure of built environment performance. Compliance-achieving rectification recommendations are the main output, along with cost estimates. Legislation interrogation and user preferences are not contemplated, reducing the process to a financial transaction, rather than an upholding of rights. Data obtained are not applicable at neighbourhood scale, and there is no expectation that findings will be used for any wider, community-oriented, benefit. Contemporary investigations into neighbourhood accessibility appear to have mostly emerged from non-built environment disciplinary perspectives and do not purport to be replicable assessment instruments. While the somewhat illogical nuances of built environment production are difficult to comprehend from a non-built environment perspective, clearly the built environment knowledge domain does not, generally, understand disability. ${ }^{115}$

Requiring collaboration between the built environment and disability knowledge domains and questioning of existing expert-driven assessment methods, a new tool, the Universal Mobility Index (UMI), has emerged. ${ }^{116}$ The UMI, as tool, is methodologically intended to function as a rights-based indicator of built environment accessibility for people with disability at neighbourhood scale. The existing built environment, at neighbourhood scale, encompasses a diversity of constructed forms that can be broadly categorised as: infrastructure, public buildings, commercial buildings and private dwellings. ${ }^{117}$ Drawing on the work of significant urban theorists, including Jane Jacobs and Leon Krier, Saeidi and Oktay state that 'an ideal neighbourhood that meets all users' requirements is more likely to be in a format that is widely diverse in terms of form [both built and natural], use and user'. ${ }^{118}$ Therefore, individually and collectively, countless combinations and permutations of (diverse) people-(diverse) environment interactions transpire in day-to-day travel chains, with resultant impacts on the accessibility rights of people with disabilities. 
The UMI is projected by its developers ${ }^{119}$ to be a powerful advocacy tool for people with disability and their representative organisations, succinctly summarising (by way of a number) the (in)accessibility of the existing built environment at neighbourhood scale and illuminating the policy environment contributing to same. An initial pilot study, testing the UMI and examining its strengths and weaknesses, was conducted in Kensington, Melbourne, Australia in 2011. ${ }^{120}$ It was broadly established that the tool can generate results and be undertaken in the field, albeit with some challenges. ${ }^{121}$ Consequently, it was intended that the tool, after immediate further development, be rolled out for use by, primarily, local government and DPOs. However, Green's terminal illness status precluded further development at that time.

\section{The Universal Mobility Index Tool}

Although 'human rights model of disability' was not a common term at either UMI origin or Kensington pilot, the view that people with disability have a human right to fully use the neighbourhood built environment is central. An essential, and defining, feature of the UMI is the dual componentry of built environment and policy environment. These two components are scored, in line with standard indicator-to-index protocols, with resultant values being between 0.00 (very bad, fully inaccessible) and 1.00 (very good, fully accessible). The two component values are then averaged to obtain the (final) UMI score.

The built environment component captures a snapshot of people with disabilities' lived experience of existing neighbourhood built environment accessibility. Built environment subcomponents are: infrastructure, public buildings, commercial buildings and private dwellings. Infrastructure is further segmented, as are various other subcomponents. Built environment accessibility assessment is undertaken by people with disability themselves, working in teams - another essential, and defining, characteristic of the UMI tool. The policy environment component captures a snapshot of human rights, disability discrimination legislation, and people with disabilities' effective voice in policymaking in the pilot locality/country. Policy environment subcomponents deal with human rights and legislation, and policy and representation. In contrast to conventional access auditing, policy environment evaluation is essential to UMI application.

Essential stages involved in operationalising the UMI tool are summarised in Table 2.

Table 2 Essential stages of the Universal Mobility Index (UMI) tool.

\begin{tabular}{|c|c|c|}
\hline & Stage & Description/Personnel/Tasks \\
\hline 1. & $\begin{array}{l}\text { Assemble project } \\
\text { support }\end{array}$ & $\begin{array}{l}\text { Obtain LGA, DPO and community support. Form Project Support Group, majority } \\
\text { membership to be people with disability. Define selected neighbourhood's spatial } \\
\text { boundaries. Meet 3-4 times, provide 'secretariat' services. }\end{array}$ \\
\hline 2. & $\begin{array}{l}\text { Pre-implementation } \\
\text { focus group }\end{array}$ & $\begin{array}{l}\text { Focus group with people with disability exploring lived experience, existing built } \\
\text { environment accessibility, and prioritisation of improvement. }\end{array}$ \\
\hline 3. & Mapping & $\begin{array}{l}\text { Map designated area, categorise all elements and allocate identifiers. Generate and } \\
\text { locate sample sites. Segment neighbourhood and devise most efficient routes. } \\
\text { Undertaken by UMI tool developer. }\end{array}$ \\
\hline 4. & $\begin{array}{l}\text { Built environment } \\
\text { assessment (onsite) }\end{array}$ & $\begin{array}{l}\text { Site assessment in teams of } 3-4 \text { people with differing impairments, each team to } \\
\text { have (minimum) wheelchair user and person with vision impairment. Session } \\
\text { length, max. } 1.5 \text { hours. Participation protocols in place prior to commencement, } \\
\text { but recruitment 'just in time'. }\end{array}$ \\
\hline 5. & $\begin{array}{l}\text { Policy environment } \\
\text { assessment }\end{array}$ & Completion, primarily by DPOs, of policy environment questionnaire. \\
\hline 6. & $\begin{array}{l}\text { Calculation of } \\
\text { results }\end{array}$ & $\begin{array}{l}\text { Accumulate and assemble data in required format. Undertake basic mathematical } \\
\text { calculations, in line with standard indicator/index protocols. Undertaken by UMI } \\
\text { tool developer. }\end{array}$ \\
\hline 7. & $\begin{array}{l}\text { Participants' } \\
\text { prioritisation }\end{array}$ & Prioritise (evidence-based) advocacy. ${ }^{122}$ \\
\hline
\end{tabular}


The Kensington pilot was conducted in accordance with the above format. Built environment elements $(\mathrm{n}=2101)$ within approximately $400-600 \mathrm{~m}$ in all directions from Kensington Station were classified and uniquely identified. Random sampling was applied at 90 per cent confidence interval and \pm 10 error $(\mathrm{p}<0.1)$, and the locations of the sample elements were mapped. The pilot area was divided into segments corresponding to manageable assessment sessions of around 90 minutes. Site assessors, volunteers with a range of differing impairments affecting their mobility, worked in teams and used their own lived experience to come to a consensus on the accessibility of each element inspected. The resultant five-point 'very bad' to 'very good' Likert-scale data were converted, in line with standard indicator-index protocols, to values between 0.00 (very bad, fully inaccessible) and 1.00 (very good, fully accessible). The built environment component value in Kensington was 0.48. A policy environment questionnaire was distributed to a wide range of local government and NGO/NfP stakeholders; answers were a choice of: 'yes', 'partially' or 'no'. This was then converted to an index value between 0.00 (would require all 'no' responses) and 1.00 (all 'yes' responses). The policy environment component value in Kensington was 0.64. The final UMI score, the average of the built environment and policy environment scores, was 0.56 . Weightings were not applied to any score calculations.

Built environment classifications and disaggregations, and index values for both built environment and policy environment and their respective subcomponents, are shown in Figure 1.



Figure 1 Kensington UMI results (Source: Jackson and Green, 2012).

Following calculation of all subcomponent scores and final score, participant input was sought regarding prioritisation of advocacy effort; infrastructure was unanimously considered to be the most important.

\section{Concluding Remarks}

Built environment performance assessment, in many guises, is already flourishing; it is not a weird idea. Increasingly, assessment is becoming interdisciplinary and multi-domained. The built environment at both the building scale and the urban realm is being investigated, mapped and modelled. Systematically investigating existing physical conditions, evaluating policy frameworks, and engaging the community are all well-established elements of measures aimed at improving built environment performance outcomes. But still, input from people with disability is rarely sought. Without neighbourhood-scale accessibility performance measurement tools aimed at evaluating lived experience, it is difficult to see how a well thought-out, rather than reactionary, programme of neighbourhood accessibility improvement can be determined. Informed by an understanding of the potency of disability models, the Universal Mobility Index offers a potential way forward to measure built environment accessibility performance at 
neighbourhood scale for people with disability. The validity of this proposition will be tested in further piloting to be undertaken as part of my current $\mathrm{PhD}$ studies.

\section{Declarations and Conflict of Interests}

The author declares no conflict of interests with this work.

\section{Notes}

${ }^{1}$ Newton, 'Regenerating Cities'.

${ }^{2}$ Rosso et al., 'The Urban Built Environment and Mobility in Older Adults'; UN, Department of Economic and Social Affairs, Population Division, World Population Ageing; Davis, The End of Normal; Villanueva et al., 'The Impact of the Built Environment on Health across the Life Course'; Glanz et al., 'Built Environment Assessment'; Pilkington and Ige, 'The Impact of the Built Environment on Health'.

${ }^{3}$ Jenks and Demsey, 'Defining the Neighbourhood'; National Heart Foundation of Australia, Good for Busine \$; Bevan and Croucher, Lifetime Neighbourhoods; Sanaz and Oktay, 'Diversity for Better Quality of Community Life'; Oliver et al., 'Associations Between the Neighbourhood Built Environment and Out of School Physical Activity and Active Travel'; Medved, 'The Structural Model of Autonomous Sustainable Neighbourhoods'; Ortolani, 'The Importance of Neighbourhood for Urban Resilience'; Whitfield, 'Measuring the Performance of Sustainable Communities'.

${ }^{4}$ Jackson, 'Models of Disability and Human Rights'.

${ }^{5}$ Castanheira and Braganca, 'The Evolution of the Sustainability Assessment Tool SBTool'; Ameen et al., 'A Critical Review of Environmental Assessment Tools for Sustainable Urban Design'; Gibberd, 'Measuring Capability for Sustainability'; Newton, 'Innovation for Sustainable Low Carbon Built Environment'; Arcadis, Chasing Mobility; Park et al., 'Critical Review of the Material Criteria of Building Sustainability Assessment Tools'; UN Settlements Programme, Building Sustainability Assessment and Benchmarking; Bannister, 'So We Have Done NABERS'; Boeing, 'Measuring the Complexity of Urban Form and Design'; Newton et al., 'Precinct Information Modelling'.

${ }^{6}$ Commonwealth of Australia, Equipment Energy Efficiency Program.

${ }^{7}$ World Green Building Council, http://www.worldgbc.org/thecommitment.

${ }^{8}$ World Green Building Council, http://www.worldgbc.org/thecommitment.

${ }^{9}$ Windows Energy Rating Scheme, https://www.wers.net/werscontent/about-wers.

${ }^{10}$ Water Rating, http://www.waterrating.gov.au/about/standards.

${ }^{11}$ Nationwide House Energy Rating Scheme (NatHERS), http://www.nathers.gov.au/.

${ }^{12}$ National Australian Built Environment Rating System, https://www.nabers.gov.au/about/what-nabers.

${ }^{13}$ Green Building Council Australia, https://new.gbca.org.au/.

${ }^{14}$ International Passive House Association, https://passivehouse-international.org/index.php.

${ }^{15}$ Leadership in Energy and Environmental Design, https://new.usgbc.org/.

16 The BRE Group, https://bregroup.com.

${ }^{17}$ The Built Environment Sustainability Tool (BEST), http://builtenvironmentsustainabilitytool.blogspot. com/p/using-tool.html.

${ }^{18}$ International Initiative for a Sustainable Built Environment, http://www.iisbe.org/sbmethod.

${ }^{19}$ Comprehensive Assessment System for Built Environment Efficiency, http://www.ibec.or.jp/CASBEE/ english/.

${ }^{20}$ G-SEED, http://www.kieae.kr/_common/do.php?a=full\&b=12\&bidx=156\&aidx=1803.

${ }^{21}$ Vietnam Green Building Council, https://vgbc.vn/en/about-vgbc/.

${ }^{22}$ Green Rating for Integrated Habitat Assessment, http://www.grihaindia.org/.

${ }^{23}$ International Living Future Institute, https://access.living-future.org/ilfi/about/history-0.

${ }^{24}$ Living Future Institute, Australia, https://living-future.org.au/living-building-challenge/.

${ }^{25}$ McManus and Taylor, 'The Changing Nature of Life Cycle Assessment'; Guinee et al., 'Life Cycle Assessment'.

${ }^{26}$ Guinee et al., 'Life Cycle Assessment'. 
27 The Building Services Research and Information Association, https://www.bsria.co.uk/about/; The Indian Society of Heating, Refrigerating and Air Conditioning Engineers (ISHRAE), http:// ishrae.in/newsdetails/ISHRAE-Releases-IEQ-Standard-/771; International Society of Indoor Air Quality and Climate, https://www.isiaq.org/about_us.php; Building Occupants Survey System, Australia, http: //www.bossasystem.com/.

${ }^{28}$ Johnson, 'Mirvac's HQ at 200 George Receives Australia's First International Well Building Institute Certification'; IWBI International Well Building Institute, 'The WELL Building Standard Version 1.0.'

${ }^{29}$ WELL v2, Pilot, https://v2.wellcertified.com/v2.1/en/overview.

${ }^{30}$ IWBI International Well Building Institute, 'The WELL Building Standard Version 1.0.'; WELL v2 Pilot, https://v2.wellcertified.com/v2.1/en/community/feature/13.

${ }^{31}$ IWBI International Well Building Institute, 'The WELL Building Standard Version 1.0.'; Newton, 'Innovation for Sustainable Low Carbon Built Environment'; Bannister, 'So We Have Done NABERS'.

32 Johnson, 'Data, Occupant Wellbeing and Flexibility'.

33 Jackson, 'Models of Disability and Human Rights'.

${ }^{34}$ Leff and Petersen, Beyond the Scorecard; Monzon, 'Smart Cities Concept and Challenges'.

35 OECD, 'Resilient Cities'.

36 O'Neill and Simard, 'Choosing Indicators to Evaluate Healthy Cities Projects'; WHO and UN Development Programme, 'Health in SDGs'.

${ }^{37}$ Barrett et al., 'The Ethical City'.

${ }^{38}$ Department for Transport and Communities and Local Government, Manual for Streets; Chartered Institution of Highways \& Transportation, Manual for Streets 2; Heaslip et al., 'Implementation of Road Safety Audit Recommendations'; Welle et al., Cities Safer by Design; Karndacharuk et al., 'Analysis of Pedestrian Performance in Shared-Space Environments'; Karndacharuk et al., 'Qualitative Evaluation Study of Urban Shared Spaces in New Zealand'; Geers et al., 'Roads are Places Too!'; Arcadis, Chasing Mobility.

39 Murray and Wu, 'Accessibility Tradeoffs in Public Transit Planning'; Gutierrez et al., 'Using Accessibility Indicators and GIS to Assess Spatial Spillovers of Transport Infrastructure Investment'; Deloitte, Infrastructure Capability Assessment Transport.

${ }^{40}$ Soubra and Antipolis, Bridging the Gap between Building Information Modelling and Geospatial Information; buildingSMART Australia and SIBA, Integration of Geospatial and Built Environment; Boeing, 'OSMnx'; Newton et al., 'Precinct Information Modelling'.

${ }^{41}$ Babb et al., 'Developing Neighbourhood "Walkability" Indices for Children's Active Transport'; Schipperijn et al., 'Dynamic Accuracy of GPS Receivers for Use in Health Research'.

42 El-Mekawy et al., 'A Unified Building Model for 3D Urban GIS'.

${ }^{43}$ Arcadis, Chasing Mobility.

${ }^{44}$ Ewing et al., 'Identifying and Measuring Urban Design Qualities Related to Walkability'; Sipe et al., 'Measuring Urban Form'; Ameen et al., 'A Critical Review of Environmental Assessment Tools for Sustainable Urban Design'; Harvey and Aultman-Hall, 'Urban Streetscape Design and Crash Severity'; Boeing, 'Measuring the Complexity of Urban Form and Design'.

${ }^{45}$ Department for Transport and Communities and Local Government, Manual for Streets; Chartered Institution of Highways \& Transportation, Manual for Streets 2; Heaslip et al., 'Implementation of Road Safety Audit Recommendations'; Welle et al., Cities Safer by Design; Geers et al. 'Roads are Places Too!' ${ }^{46}$ Brownson et al., 'Measuring the Built Environment for Physical Activity'; Rosso, 'The Urban Built Environment and Mobility in Older Adults'; Burton et al., 'Good Places for Ageing in Place'; Appleyard, 'New Methods to Measure the Built Environment for Human-Scale Travel Research'; Office of Policy and Planning, San Francisco Healthy Homes Project; Kent et al., Healthy Built Environments; Wilson et al., 'Assessing the Built Environment Using Omnidirectional Imagery'; Frank et al., Health and the Built Environment; Geers et al., 'Roads are Places Too!'; Rollings et al., 'Measuring Physical Neighbourhood Quality Related to Health'; Glanz, 'Built Environment Assessment'.

${ }^{47}$ Appleyard, 'New Methods to Measure the Built Environment for Human-Scale Travel Research'.

${ }^{48}$ Kent et al., Healthy Built Environments. 
49 Jackson, 'Models of Disability and Human Rights'.

${ }^{50}$ Fisher, 'Trends in Institutional Care of the Aged'; Wolfensberger, 'The Origin and Nature of Our Institutional Models'; Imrie, 'Oppression, Disability and Access in the Built Environment'; Braddock and Parish, 'An Institutional History of Disability'; Pfeiffer, 'The Conceptualization of Disability'; Barnes and Mercer, Disability; Peace, 'The Development of Residential and Nursing Home Care in the United Kingdom'; Higginbotham, 'The Workhouse'; Jackson, 'Models of Disability and Human Rights'.

${ }^{51}$ Braddock and Parish, 'An Institutional History of Disability'.

${ }^{52}$ Braddock and Parish, 'An Institutional History of Disability'; Wolfensberger, 'The Origin and Nature of Our Institutional Models'; Barnes and Mercer, Disability; Imrie, 'Oppression, Disability and Access in the Built Environment'.

53 Jackson, 'Models of Disability and Human Rights'; Higginbotham, 'The Workhouse'; Peace, 'The Development of Residential and Nursing Home Care in the United Kingdom'; Fisher, 'Trends in Institutional Care of the Aged'.

${ }^{54}$ Imrie, 'Oppression, Disability and Access in the Built Environment'. 129.

55 Oliver, 'Theories in Health Care and Research'; Scotch, 'Models of Disability and the Americans with Disabilities Act'; Pfeiffer, 'The Conceptualization of Disability'.

${ }^{56}$ Nankervis, 'Conceptions of Disability'.

57 Jackson, 'Models of Disability and Human Rights'; Oliver, 'Theories in Health Care and Research'; Scotch, 'Models of Disability and the Americans with Disabilities Act'; Pfeiffer, 'The Conceptualization of Disability'; Stainton, 'Intellectual Disability, Oppression and Difference'.

58 Pfeiffer, 'The Conceptualization of Disability'; Stainton, 'Intellectual Disability, Oppression and Difference'; Jackson, 'Models of Disability and Human Rights'.

${ }^{59}$ Hunt, 'A Critical Condition'; Finkelstein, 'Disability'; Finkelstein, A Personal Journey into Disability Politics; West, 'What Do We Mean by Support?'

${ }^{60}$ West, 'What Do We Mean by Support?'

${ }^{61}$ Soder, 'Tensions, Perspectives and Themes in Disability Studies'.

${ }^{62}$ Oliver, Social Work with Disabled People; Oliver, 'Theories in Health Care and Research'; Oliver, 'The Social Model of Disability'; Scotch, 'Models of Disability and the Americans with Disabilities Act'; Pfeiffer, 'The Conceptualization of Disability'.

${ }^{63}$ Oliver, Social Work with Disabled People; Finkelstein, 'Disability'; Oliver, 'Theories in Health Care and Research'; Scotch, 'Models of Disability and the Americans with Disabilities Act'; Pfeiffer, 'The Conceptualization of Disability'; Soder, 'Tensions, Perspectives and Themes in Disability Studies'; West, 'What Do We Mean by Support?'

${ }^{64}$ Quinn et al., Human Rights and Disability; Degener, 'Disability in a Human Rights Context'.

${ }^{65}$ Berghs et al., 'Implications for Public Health Research of Models and Theories of Disability'.

${ }^{66}$ Quinn et al., Human Rights and Disability; Bruce, 'Which Entitlements and for Whom?'; Schindler, 'Architectural Exclusion'; Berghs et al., 'Implications for Public Health Research of Models and Theories of Disability'; Degener, 'Disability in a Human Rights Context'.

${ }^{67}$ UN, Convention on the Rights of Persons with Disabilities.

${ }^{68}$ Bruce, 'Which Entitlements and for Whom?'

${ }^{69}$ Degener, 'Disability in a Human Rights Context'.

${ }^{70} \mathrm{UN}$, Convention on the Rights of Persons with Disabilities.

${ }^{71}$ Australian Government, Disability Discrimination Act (DDA) 1992 (as Amended); Jackson, 'Models of Disability and Human Rights'.

${ }^{72}$ Imrie, and Wells. 'Disablism, Planning, and the Built Environment'; Imrie, 'Oppression, Disability and Access in the Built Environment'; Ostroff, 'Universal Design'; Imrie, 'Doing Disability Differently': Boys, Doing Disability Differently; Hamraie, 'Universal Design and the Problem of "Post-Disability" Ideology'; Larkin et al., 'Working with Policy and Regulatory Factors to Implement Universal Design in the Built Environment'; Boys, 'Introduction'; Jackson and Green, 'The Role of Access in Achieving Healthy Buildings'; McLaughlin et al., 'Beyond Construction'.

${ }^{73}$ Jackson and Green, 'The Role of Access in Achieving Healthy Buildings'. 
${ }^{74}$ Jackson and Green, 'Accessible Parking'.

75 Williams et al., Creativity, Design and Education; Heylighen, 'About the Nature of Design in Universal Design'; Maturana, 'Where is the "Problem" in Design Studio'.

${ }^{76}$ Beza, 'The Role of Deliberative Planning in Translating Best Practice into Good Practice'; McLaughlin, 'Beyond Construction'; Larkin et al., 'Working with Policy and Regulatory Factors to Implement Universal Design in the Built Environment'; Hamraie, 'Universal Design and the Problem of "Post-Disability" Ideology'; Boys, 'Introduction'.

77 Boys, 'Introduction'.

${ }^{78}$ Boys, 'Introduction'.

79 Boeing, 'Measuring the Complexity of Urban Form and Design'.

${ }^{80}$ Yigitcanlar and Dur, 'Developing a Sustainability Assessment Model'; Castanheira and Braganca, 'The Evolution of the Sustainability Assessment Tool SBTool'; Ameen et al., 'A Critical Review of Environmental Assessment Tools for Sustainable Urban Design'.

${ }^{81}$ Ewing et al., 'Identifying and Measuring Urban Design Qualities Related to Walkability'.

${ }^{82}$ Sipe et al., 'Measuring Urban Form'.

${ }^{83}$ Ewing et al., 'Identifying and Measuring Urban Design Qualities Related to Walkability'; ECOVAST, Landscape Identification; Tudor, An Approach to Landscape Character Assessment.

${ }^{84}$ Project for Public Spaces and Metropolitan Planning Council, A Guide to Neighborhood Placemaking in Chicago, 1

${ }^{85}$ Project for Public Spaces and Metropolitan Planning Council, A Guide to Neighborhood Placemaking in Chicago; Dixon, Sustainable Urban Development to 2050; Carmona, 'The Place-shaping Continuum'.

${ }^{86}$ Pugalis, 'The Evolutionary "waves" of place-shaping'.

${ }^{87}$ Pugalis, 'The Evolutionary "waves" of place-shaping', 3.

${ }^{88}$ Geers et al., 'Roads are Places Too!'

${ }^{89}$ Healthy Spaces \& Places, The Healthy Spaces and Places Manual; VicHealth, 'Arts and Social Connection'.

${ }^{90}$ Deane, Shut Out.

91 Timperio et al., 'Neighbourhood Physical Activity Environments and Adiposity in Children and Mothers'; Tappe et al., 'Children's Physical Activity and Parents' Perception of the Neighborhood Environment'; Oliver et al., 'Associations between the Neighbourhood Built Environment and out of School Physical Activity and Active Travel'; Gong et al., 'Neighbourhood Green Space, Physical Function and Participation in Physical Activities Among Elderly Men'; Nyunt et al., 'Objective and Subjective Measures of Neighborhood Environment (NE)'.

${ }^{92}$ Rosenberg et al., 'Outdoor Built Environment Barriers and Facilitators to Activity among Midlife and Older Adults with Mobility Disabilities'; Musselwhite, 'To Keep Older People Active Pedestrian Accessibility Must improve'; Barnett et al., 'Associations between the Neighbourhood Environment Characteristics and Physical Activity in Older Adults with Specific Types of Chronic Conditions'; Cerin et al., 'The Neighbourhood Physical Environment and Active Travel in Older Adults'.

${ }^{93}$ Philibert et al. 'Conceptual and Operational Considerations in Identifying Socioenvironmental Factors Associated with Disability among Community-Dwelling Adults'; Cordier et al., 'A Systematic Review Evaluating the Psychometric Properties of Measures of Social Inclusion'.

${ }^{94}$ Philibert et al., 'Conceptual and Operational Considerations in Identifying Socioenvironmental Factors Associated with Disability among Community-Dwelling Adults'.

${ }^{95}$ Imrie and Kumar, 'Focusing on Disability and Access in the Built Environment'; Surface, Towards Access Standards; Deane, Shut Out, 42; House of Commons, 'Building for Equality'.

${ }^{96}$ An example, based in Melbourne, is the All Aboard Network, which is concerned with people with disabilities access to (all forms of) transport throughout Victoria.

${ }^{97}$ JENNY PEARSON \& ASSOCIATES PTY LTD. Research of the Models of Advocacy Funded under the national Disability Advocacy Program.

${ }^{98}$ Heart Foundation, https://www.heartfoundation.org.au/; Healthy Spaces \& Places, The Healthy Spaces \& Places Manual. 
${ }^{99}$ D'Haese et al., 'The Association between Objective Walkability, Neighborhood Socio-Economic Status, and Physical Activity in Belgian children'; Lindelow et al. 'What Limits the Pedestrian?'; Nyunt et al., 'Objective and Subjective Measures of Neighborhood Environment (NE)'; Tilley et al., 'Older People's Experiences of Mobility and Mood in an Urban Environment'.

100 Priestley et al., 'New Priorities for Disability Research in Europe'.

${ }^{101}$ Centre for Disability Research and Policy, Report of Audit of Disability Research in Australia.

${ }^{102}$ Realpe and Wallace, What is Co-Production?; Burkett, An Introduction to Co-Design; Sutto-Long et al., Co-Design for Community Inclusion.

${ }^{103}$ Imrie and Wells. 'Disablism, Planning, and the Built Environment'; Imrie, 'Disabling Environments and the Geography of Access Policies and Practices'.

${ }^{104}$ McSherry, Australia's International Human Rights Obligation; Australian Law Reform Commission, 'Equality, Capacity and Disability in Commonwealth Laws'.

105 Jackson, 'Models of Disability and Human Rights'.

106 Coni-Zimmer et al., 'Editorial to the Issue on Legitimization of Private and Public Regulation'; Howlett et al., 'Policy Integration and Multi-Level Governance'; Tschoerner, 'A Governance Approach to Sustainable Mobility'; Andersen and Larsen, 'Social inclusion and Spatial Inequality in the City'.

107 Jackson, 'Models of Disability and Human Rights'; House of Commons, 'Building for Equality'.

108 Jackson, 'Models of Disability and Human Rights'.

109 Jackson, 'Models of Disability and Human Rights'.

110 Jackson, 'Models of Disability and Human Rights'.

111 Boys, Doing Disability Differently; Imrie, 'Doing Disability Differently'; Jackson, 'Models of Disability and Human Rights'.

112 Chan and Cooper, 'Governance in Construction'.

113 Green, 'An Introductory Theoretical and Methodological Framework for a Universal Mobility Index (UMI) to Quantify, Compare, and Longitudinally Track Equity of Access across the Built Environment'; Jackson, 'The Role of Access in Achieving Healthy Buildings'; Jackson, 'Models of Disability and Human Rights'.

114 Jackson, 'Models of Disability and Human Rights'.

115 Jackson, 'Models of Disability and Human Rights'.

${ }^{116}$ Green, 'An Introductory Theoretical and Methodological Framework for a Universal Mobility Index (UMI) to Quantify, Compare, and Longitudinally Track Equity of Access across the Built Environment'. 117 Green, 'An Introductory Theoretical and Methodological Framework for a Universal Mobility Index (UMI) to Quantify, Compare, and Longitudinally Track Equity of Access across the Built Environment'; Jackson, 'The Role of Access in Achieving Healthy Buildings'.

118 Saeidi and Oktay, 'Diversity for Better Quality of Community Life', 497.

${ }^{119}$ Green, Jackson (author), and Visionary Design Development Pty Ltd, co-founded by Green and Jackson.

${ }^{120}$ Forming part of the author's master's degree research project.

${ }^{121}$ Jackson, 'Assessing Accessibility in the Built Environment using a Participatory Approach'; Jackson, 'The Role of Access in Achieving Healthy Buildings'.

122 As an example, in Kensington although 'commercial buildings' was the worst-performing built environment category, participants unanimously prioritised Infrastructure as the most important category at which to direct advocacy efforts.

\section{References}

Ameen, Raed Fawzi Mohammed, Monjur Mourshed, and Haijiang Li. 'A Critical Review of Environmental Assessment Tools for Sustainable Urban design'. Environmental Impact Assessment Review 55 (2015): 110-25. [CrossRef]

Andersen, John, and Jorgen Elm Larsen. 'Social Inclusion and Spatial Inequality in the City: The Danish Case'. Paper presented at the Australian Social Policy Conference, Sydney, Australia, 9-11 July 2003. 
Appleyard, Bruce. 'New Methods to Measure the Built Environment for Human-Scale Travel Research: Individual Access Corridor (IAC) Analytics to Better Understand Sustainable Active Travel Choices'. The Journal of Transport and Land Use 9, no. 2 (2016): 121-45. [CrossRef]

Arcadis. Chasing Mobility: Moving towards a Connected Sustainable Future. Sydney: Arcadis Australia Pacific, 2017.

Australian Government. Disability Discrimination Act (DDA) 1992 (as Amended). Canberra: Office of Parliamentary Counsel, 1992.

Australian Law Reform Commission. 'Equality, Capacity and Disability in Commonwealth Laws'. Accessed 22 August 2019. https://www.alrc.gov.au/publications/equality-capacity-and-disabilitycommonwealth-laws/legislative-and-regulatory-framework.

Babb, Courtney, Mathew Burke, and Paul. Tranter. 'Developing Neighbourhood "Walkability" Indices for Children's Active Transport'. Paper presented at the World Planning Schools Congress 2011: Planning in an Era of Uncertainty and Transformation, Perth, Australia, 4-8 July 2011.

Bannister, Paul. 'So we have done NABERS. Now what?'. Ecolibrium 16, no. 2 (2017): 38-41.

Barnes, Colin, and Geof Mercer. Disability. Cambridge: Polity Press, 2003.

Barnett, Anthony, Ester Cerin, Casper J. P. Zhang, Cindy H. P. Sit, Janice M. Johnston, Martin M. C. Cheung, and Ruby S. Y. Lee. 'Associations Between the Neighbourhood Environment Characteristics and Physical Activity in Older Adults with Specific Types of Chronic Conditions: The ALECS Cross-Sectional Study'. International Journal of Behavioral Nutrition and Physical Activity 13 (2016): 53. [CrossRef] [PubMed]

Barrett, Brendan F. D., Ralph Horne, and John Fien. 'The Ethical City: A Rationale for an Urgent New Urban Agenda'. Sustainability 8, no. 11 (2016): 1197. [CrossRef]

Berghs, Maria, Karl Atkins, Hilary Graham, Chris Hatton, and Carol Thomas. 'Implications for Public Health Research of Models and Theories of Disability: A Scoping Study and Evidence Synthesis'. Public Health Research 4, no. 8 (2016). [CrossRef]

Bevan, Mark, and Karen Croucher. Lifetime Neighbourhoods; London: Department for Communities and Local Government, 2011.

Beza, Beau. 'The Role of Deliberative Planning in Translating Best Practice into Good Practice: From Placeless-Ness to Placemaking'. Planning Theory \& Practice 17, no. 2 (2014): 244-63. [CrossRef]

Boeing, Goeff. 'Measuring the Complexity of Urban Form and Design'. Urban Design International 23, no. 4 (2017): 281-92. [CrossRef]

Boeing, Geoff. 'OSMnx: New Methods for Acquiring, Constructing, Analyzing, and Visualizing Complex Street Networks'. Computers, Environment and Urban Systems 65 (2017): 126-39. [CrossRef]

BOSSA (Building Occupants Survey System Australia). 'What Is BOSSA?'. Accessed 22 August 2019. http://www.bossasystem.com/.

Boys, Jos. Doing Disability Differently. Oxford: Routledge, 2014.

Boys, Jos. 'Introduction'. In Disability, Space, Architecture: A Reader, edited by Jos Boys, 1-6. London: Routledge, 2017.

Braddock, David L., and Susan L. Parish. 'An Institutional History of Disability'. In Handbook of Disability Studies, 2nd ed., edited by Gary L. Albrecht, Katherine D. Seelman and Michael Bury, 11-68. Thousand Oaks, CA: Sage, 2001.

BRE Group. 'About us'. Accessed 22 August 2019. https://bregroup.com/about-us.

Brownson, Ross C., Christine M. Hoehner, Kristen Day, Ann Forsyth, and James F. Sallis. 'Measuring the Built Environment for Physical Activity: State of the Science'. American Journal of Preventive Medicine 36, no. 4 Suppl. (2009): S99-S123. [CrossRef] [PubMed]

Bruce, Anna. Which Entitlements and for Whom? The Convention on the Rights of Persons with Disabilities and Its Ideological Antecedents. Lund: Lund University, 2014.

Building Services Research and Information Association. 'About BSRIA'. Accessed 22 August 2019. https://www.bsria.co.uk/about/. 
buildingSMART Australia and SIBA. Integration of Geospatial and Built Environment: National Data Policy, 2015. Accessed 22 August 2019. https://buildingsmart.org.au/wp-content/uploads/ DigitalBuiltEnvironment-SpatialConstructionInformation-150718.pdf.

Built Environment Sustainability Tool (BEST). 'Built Environment Sustainability Tool'. Accessed 22 August 2019. http://builtenvironmentsustainabilitytool.blogspot.com/p/using-tool.html.

Burkett, Ingrid. An Introduction to Co-Design. Accessed 22 August 2019. https://www.yacwa.org.au/wpcontent/uploads/2016/09/An-Introduction-to-Co-Design-by-Ingrid-Burkett.pdf.

Burton, Elizabeth J., Lynne Mitchell, and Chris B. Stride. 'Good Places for Ageing in Place: Development of Objective Built Environment Measures for Investigating Links with Older People's Wellbeing'. BMC Public Health 11, no. 1 (2011): 839. [CrossRef]

Carmona, Matthew. 'The Place-Shaping Continuum: A Theory of Urban Design Process'. Journal of Urban Design 19, no. 1 (2014): 2-36. [CrossRef]

Castanheira, Guilherme, and Luis Braganca. 'The Evolution of the Sustainability Assessment Tool SBTool: From Buildings to the Built Environment'. The Scientific World Journal 2014 (2014): 491791. [CrossRef]

Centre for Disability Research and Policy. Report of Audit of Disability Research in Australia. Sydney: University of Sydney, 2014.

Cerin, Ester, Andrea Natha, Jelle van Cauwenberg, David W. Barnett, and Anthony Barnett. 'The Neighbourhood Physical Environment and Active Travel in Older Adults: A Systematic Review and Meta-Analysis'. International Journal of Behavioral Nutrition and Physical Activity 14 (2017): 15. [CrossRef]

Chan, Paul, and Rachel Cooper. 'Governance in Construction: The Trends of Privatisation and Community Engagement'. In Constructing Futures: Industry Leaders and Futures Thinking in Construction, edited by Paul Chan and Rachel Cooper, 155-76. Hoboken, NJ: Wiley, 2010.

Chartered Institution of Highways \& Transportation. Manual for Streets 2: Wider Application of the Principles. London: Chartered Institution of Highways \& Transportation, 2010.

Commonwealth of Australia. Equipment Energy Efficiency Program, 2009. Accessed 22 August 2019. http://energyrating.gov.au/sites/new.energyrating/files/documents/200914-achievements_0.pdf.

Comprehensive Assessment System for Built Environment Efficiency. Accessed 22 August 2019. http://www.ibec.or.jp/CASBEE/english/.

Coni-Zimmer, Melanie, Klaus Dieter Wold, and Peter Collin. 'Editorial to the Issue on Legitimization of Private and Public Regulation: Past and Present'. Politics and Governance 5, no. 1 (2017): 1-5. [CrossRef]

Cordier, Reinie, Ben Milbourn, Robyn Martin, Angus Buchanan, Donna Chung, and Renee Speyer. 'A Systematic Review Evaluating the Psychometric Properties of Measures of Social Inclusion'. PLoS ONE 12, no. 6 (2017): e0179109. [CrossRef]

Davis, Lennard. The End of Normal: Identity in a Biocultural Era. Ann Arbor: University of Michigan Press, 2014.

Deane, Kirsten. Shut Out: The Experience of People with Disabilities and Their Families in Australia. Canberra: National People with Disabilities and Carer Council, 2009.

Degener, Theresia. 'Disability in a Human Rights Context'. Laws 5, no. 3 (2016): 35. [CrossRef]

Deloitte. Infrastructure Capability Assessment Transport: Infrastructure Victoria, 2016. Accessed 22 August 2019. https://www.infrastructurevictoria.com.au/wp-content/uploads/2019/04/160229Transport-Final-1.pdf.

Department for Transport and Communities and Local Government. Manual for Streets. London: Thomas Telford Publishing, 2007.

D’Haese, Sara, Delfien Van Dyck, Ilse De Bourdeaudhuij, Benedicte Deforche, and Greet Cardon. The Association between Objective Walkability, Neighborhood Socio-Economic Status, and Physical Activity in Belgian children'. International Journal of Behavioral Nutrition and Physical Activity 11 (2014): 104. [CrossRef] 
Dixon, Tom. 'Sustainable Urban Development to 2050: Complex Transitions in the Built Environment of Cities'. Retrofit (2011).

ECOVAST. Landscape Identification: A Guide to Good Practice, 2006. Accessed 22 August 2019. http://www.ecovast.org/papers/good_guid_corr_e.pdf.

El-Mekawy, Mohamed, Anders Ostman, and Ihab Hijazi. 'A Unified Building Model for 3D Urban GIS'. ISPRS International Journal of Geo-Information 1 (2012): 120-45. [CrossRef]

Ewing, Reid, Susan Handy, Ross C. Brownson, Otto Clemente, and Emily Winston. 'Identifying and Measuring Urban Design Qualities Related to Walkability'. Journal of Physical Activity and Health 3 (2007): S223-40. [CrossRef]

Finkelstein, Vic. 'Disability: A Social Challenge or an Administrative Responsibility?'. In Disability Barriers - Enabling Environments, edited by John Swain, Sally French, Colin Barnes and Carol Thomas. London: Sage, 1993.

Finkelstein, Vic. A Personal Journey into Disability Politics. Leeds: Leeds University Centre for Disability Studies, 2001.

Fisher, Jacob. 'Trends in Institutional Care of the Aged'. The Bulletin, October 1953.

Frank, Lawrence, Sarah Kavage, and Andrew Devlin. Health and the Built Environment: A Review, 2012. Accessed 22 August 2012. http://urbandesign4health.com/wp-content/uploads/2012/10/Built_EnvFinal_Report-August2012.pdf.

Geers, Glenn, Auttapone Karndacharuk, Nathan Chen, Bryan Willey, and Mary Haverland. 'Roads are Places Too! Developing a Multi-Modal Movement and Place Evaluation Framework for New South Wales'. Paper presented at the 27th ARRB Conference - Linking People, Places and Opportunities, Melbourne, Victoria, Australia, 16-18 November 2016.

Gibberd, Jeremy. 'Measuring Capability for Sustainability: The Built Environment Sustainability Tool (BEST)'. Building Research \& Information 43, no. 1 (2015): 49-61. [CrossRef]

Glanz, Karen, Susan L. Handy, Kathryn E. Henderson, Sandy J. Slater, Erica L. Davis, and Lisa M. Powell. 'Built Environment Assessment: Multidisciplinary Perspectives'. SSM - Population Health 2 (2016): 24-31. [CrossRef]

Gong, Yi, John Gallacher, Stephen Palmer, and David Fone. 'Neighbourhood Green Space, Physical Function and Participation in Physical Activities among Elderly Men: The Caerphilly Prospective Study'. International Journal of Behavioral Nutrition and Physical Activity 11 (2014): 40. [CrossRef]

Green Building Council Australia. Accessed 22 August 2012. https://new.gbca.org.au/.

Green, Ralph J. 'An Introductory Theoretical and Methodological Framework for a Universal Mobility Index (UMI) to Quantify, Compare, and Longitudinally Track Equity of Access across the Built Environment'. Disability Policy Studies 21, no. 4 (2011): 219-29. [CrossRef]

Green Rating for Integrated Habitat Assesment. Accessed 22 August 2019. http://www.grihaindia.org/.

G-SEED. Accessed 22 August 2019. http://www.kieae.kr/_common/do.php?a=full\&b=12\&bidx=156\& aid $x=1803$.

Guinee, Jeroen B., Reinout Heijungs, and Gjalt Huppes. 'Life Cycle Assessment: Past, Present, and Future'. Environmental Science \& Technology 45, no. 1 (2011): 90-6. [CrossRef]

Gutierrez, Javier, Ana Condeco-Melhorado, and Juan Carlos Martin. 'Using Accessibility Indicators and GIS to Assess Spatial Spillovers of Transport Infrastructure Investment'. Journal of Transport Geography 18 (2010): 141-52. [CrossRef]

Hamraie, Aimi. 'Universal Design and the Problem of "Post-Disability" Ideology'. Design and Culture 8, no. 3 (2016): 285-309. [CrossRef]

Harvey, Chester, and Lisa Aultman-Hall. 'Urban Streetscape Design and Crash Severity'. Transportation Research Record: Journal of the Transportation Research Board 2500, no. 2 (2015): 1-8. [CrossRef]

Healthy Spaces \&. Places. The Healthy Spaces \& Places Manual: A National Guide to Designing Places for Healthy Living, 2009. Accessed 22 August 2019. http://www.healthyplaces.org.au/site/.

Heart Foundation. Accessed 22 August 2019. https://www.heartfoundation.org.au/. 
Heaslip, Kevin, Josh Jones, Tim Harpst, and Doyt Bolling. 'Implementation of Road Safety Audit Recommendations: Case Study in Salt Lake City, Utah'. Transportation Research Record: Journal of the Transportation Research Board 2182, no. 1 (2010): 105-12. [CrossRef]

Heylighen, Ann. 'About the Nature of Design in Universal design'. Disability and Rehabilitation 36, no. 16 (2014): 1360-8. [CrossRef]

Higginbotham, Peter. 'The Workhouse'. Accessed 22 August 2019. http://www.workhouses.org.uk/

House of Commons. 'Building for Equality: Disability and the Built Environment'. 2017. Accessed 22 August 2019. https://publications.parliament.uk/pa/cm201617/cmselect/cmwomeq/631/631.pdf.

Howlett, Michael, Joanna Vince, and Pablo del Rio. 'Policy Integration and Multi-Level Governance: Dealing with the Vertical Dimension of Policy Mix Designs'. Politics and Governance 5, no. 2 (2017): 69-78. [CrossRef]

Hunt, Paul. 'A Critical Condition'. In Stigma: The Experience of Disability, edited by Paul Hunt. London: Geoffrey Chapman, 1966.

Imrie, Rob. 'Disabling Environments and the Geography of Access Policies and Practices'. Disability \& Society 15 (2000): 5-24.

Imrie, Rob. 'Doing Disability Differently: An Alternative Handbook on Architecture, Dis/Ability and Designing for Everyday Life'. Disability \& Society 30 (2015): 486-8. [CrossRef]

Imrie, Rob. 'Oppression, Disability and Access in the Built Environment'. In Disability Reader: Social Science Perspectives, edited by Tom Shakespeare, 129-46. London: Bloomsbury, 1998.

Imrie, Rob, and Marion Kumar. 'Focusing on Disability and Access in the Built Environment'. Disability \& Society 13 (1998): 357-74. [CrossRef]

Imrie, Rob F., and Peter Wells. 'Disablism, Planning, and the Built Environment'. Environment and Planning C, Government and Policy 11, no. 2 (1993): 13-31. [CrossRef]

Indian Society of Heating, Refrigerating and Air Conditioning Engineers (ISHRAE). Accessed 22 August 2019. http://ishrae.in/newsdetails/ISHRAE-Releases-IEQ-Standard-/771.

International Initiative for a Sustainable Built Environment. Accessed 22 August 2019. http://www.iisbe. org/sbmethod.

International Living Future Institute. Accessed 22 August 2019. https://access.living-future.org/ilfi/about/ history-0.

International Passive House Association. Accessed 22 August 2019. https://passivehouse-international. org/index.php.

International Society of Indoor Air Quality and Climate. Accessed 22 August 2019. https://www.isiaq. org/about_us.php.

IWBI International Well Building Institute. The WELL Building Standard Version 1.0. Washington, DC: IWBI International Well Building Institute, 2014.

Jackson, Mary Ann. 'Assessing Accessibility in the Built Environment Using a Participatory Approach: Strengths and Challenges of the Universal Mobility Index'. MA dissertation, University of Melbourne, 2011.

Jackson, Mary Ann. 'Models of Disability and Human Rights: Informing the Improvement of Built Environment Accessibility for People with Disability at Neighborhood Scale?'. Laws 7, no. 10 (2018). [CrossRef]

Jackson, Mary Ann, and Ralph. Green. 'Accessible Parking: Are Users' Voices Heard within the Built Environment Sphere?'. Paper presented at the Living and Learning: Research for a Better Built Environment: 49th International Conference of the Architectural Science Association, Melbourne, Victoria, Australia, 2-4 December 2015.

Jackson, Mary Ann, and Ralph J. Green. 'The Role of Access in Achieving Healthy Buildings: Universal Mobility Index'. Paper presented at the 10th International Conference on Healthy Buildings, Brisbane, Queensland, Australia, 8-12 July 2012.

Jenks, Mike, and Nicola Demsey. 'Defining the Neighbourhood: Challenges for Empirical Research'. The Town Planning Review 78 (2007): 153-77. [CrossRef] 
Jenny Pearson \& Associates PTY LTD. Research of the Models of Advocacy Funded under the National Disability Advocacy Program. Canberra: Australia, 2010.

Johnson, Nathan. 'Data, Occupant Wellbeing and Flexibility the Future of Workspace Design'. Last modified 28 October 2016. Accessed 22 August 2019. https://www.architectureanddesign.com.au/ features/comment/data-occupant-wellbeing-and-flexibility-the-future\#.

Johnson, Nathan. 'Mirvac's HQ at 200 George Receives Australia's First International Well Building Institute Certification'. Last modified 7 March 2017. Accessed 22 August 2019. https://www. architectureanddesign.com.au/news/mirvac-s-hq-at-200-george-receives-australia-s-fir.

Karndacharuk, Auttapone, Douglas Wilson, and Roger Dunn. 'Analysis of Pedestrian Performance in Shared-Space Environments'. Transportation Research Record: Journal of the Transportation Research Board 2393 Pedestrians (2013): 1-11. [CrossRef]

Karndacharuk, Auttapone, Douglas J. Wilson, and Roger C. M. Dunn. 'Qualitative Evaluation Study of Urban Shared Spaces in New Zealand'. Transportation Research Part D 42 (2016): 119-34. [CrossRef]

Kent, J., S. M. Thompson, and B. Jalaludin. Healthy Built Environments: A Review of the Literature. Sydney: Healthy Built Environments Program, City Future Research Centre, UNSW, 2011.

Larkin, Helen, Danielle Hitch, Valerie Watchorn, and Susan Ang. 'Working with Policy and Regulatory Factors to Implement Universal Design in the Built Environment: The Australian Experience'. International Journal of Environmental Residential and Public Health 12, no. 7 (2015): 8157-71. [CrossRef]

Leadership in Energy and Environmental Design. Accessed 22 August 2019. https://new.usgbc.org/.

Leff, Scott, and Brittany Petersen. Beyond the Scorecard: Understanding Global City Rankings. Chicago: The Chicago Council on Global Affairs, 2015.

Lindelow, David, Ase Svensson, Catharina Sternudd, and Maria Johansson. 'What Limits the Pedestrian? Exploring Perceptions of Walking in the Built Environment and in the Context of Every-Day Life'. Journal of Transport \& Health 1 (2014): 223-31. [CrossRef]

Living Future Institute, Australia. Accessed 22 August 2019. https://living-future.org.au/living-buildingchallenge/.

Maturana, Beatriz C. 'Where Is the "Problem" in Design Studio: Purpose and Significance of the DesignTask'. Archnet-IJAR: International Journal of Architectural Research 8, no. 3 (2014): 32-44. [CrossRef]

McLaughlin, P., B. Kennedy, and A. Mills. 'Beyond Construction ..... A Cross-Disciplinary Approach to Improved Learning and Teaching in Built Environment Degrees'. Paper presented at the 40th Australasian Universities Building Education Association Annual Conference, Central Queensland University, Rockhampton, Queensland, Australia, 6-8 July 2016.

McManus, Marcelle C., and Caroline M. Taylor. 'The Changing Nature of Life Cycle Assessment'. Biomass and Bioenergy 82 (2015): 13-26. [CrossRef]

McSherry, Bernadette. Australia's International Human Rights Obligation. Gladesville: Mental Health Commission of New South Wales, 2014.

Medved, Primoz. 'The Structural Model of Autonomous Sustainable Neighbourhoods: New (Social) Basis for Sustainable Urban Planning'. Paper presented at the 17th European Roundtable on Sustainable Consumption and Production, Portorož, Slovenia, 14-16 October 2014.

Monzon, Andres. 'Smart Cities Concept and Challenges: Bases for the Assessment of Smart City Projects'. In Smart Cities, Green Technologies, and Intelligent Transport Systems, edited by Brian Donnellan, Cornel Klein, Markus Helfert, Oleg Gusikhin and António Pascoal. Cham: Springer, 2015.

Murray, Alan T., and Xiaolan Wu. 'Accessibility Tradeoffs in Public Transit Planning'. Journal of Geographical Systems 5, no. 1 (2003): 93-107. [CrossRef]

Musselwhite, Charles. 'To Keep Older People Active Pedestrian Accessibility Must Improve'. The Conversation. Last modified 24 October 2016. Accessed 22 August 2019. https://theconversation.com/to-keepolder-people-active-pedestrian-accessibility-must-improve- 65134. 
Nankervis, Karen. 'Conceptions of Disability'. In Community Disability Services: An Evidence-Based Approach to Practice, edited by Ian Dempsey and Karen Nankervis, 3-26. Sydney: UNSW Press, 2006.

National Australian Built Environment Rating System. Accessed 22 August 2019. https://www.nabers. gov.au/about/what-nabers.

National Heart Foundation of Australia. Good for Busine\$\$: The Benefits of Making Streets More Walking and Cycling Friendly, 2011. Accessed 22 August 2019. https://www.heartfoundation.org.au/images/ uploads/publications/Good-for-business.pdf.

Nationwide House Energy Rating Scheme (NatHERS). Accessed 22 August 2019. http://www.nathers. gov.au/.

Newton, Peter W. 'Regenerating Cities: Technological and Design Innovation for Australian Suburbs'. Building Research \& Information 41 (2013): 575-88. [CrossRef]

Newton, Peter W. 'Innovation for Sustainable Low Carbon Built Environment'. Procedia Engineering 180 (2017): 16-32. [CrossRef]

Newton, Peter, Jim Plume, David Marhant, John Mitchell, and Tuan Ngo. 'Precinct Information Modelling: A New Digital Platform for Integrated Design, Assessment and Management of the Built Environment'. In Integrating Information in Built Environments, edited by Adriana X. Sanchez, Keith Hampson and Geoffrey London, 111-32. Abingdon: Routledge, 2017.

Nyunt, Ma Shwe Zin, Faysal Kabir Shuvo, Jia Yen Eng, Keng Bee Yap, Samuel Scherer, Li Min Hee, Siew Pang Chan, and Tze Pin Ng. 'Objective and Subjective Measures of Neighborhood Environment (NE): Relationships with Transportation Physical Activity among Older Persons'. International Journal of Behavioral Nutrition and Physical Activity 12 (2015): 108. [CrossRef]

OECD. 'Resilient Cities'. Accessed 22 August 2019. https://www.oecd.org/cfe/regional-policy/resilientcities.htm.

Office of Policy and Planning. San Francisco Healthy Homes Project: Community Health Status Assessment, 2006. Accessed 22 August 2019. https://sfenvironment.org/sites/default/files/fliers/ files/sfe_ej_sfhh_community_health_status_assessment.pdf.

Oliver, Melody, Suzanne Mavoa, Hannah Badland, Karl Parker, Phil Donovan, Robin A Kearns, En-Yi Lin, and Karen Witten. 'Associations between the Neighbourhood Built Environment and Out of School Physical Activity and Active Travel: An Examination from the Kids in the City Study'. Health \& Place 36 (2015): 57-64. [CrossRef]

Oliver, Mike. Social Work with Disabled People. Basingstoke: MacMillan, 1983.

Oliver, Michael. 'Theories in Health Care and Research: Theories of Disability in Health Practice and Research'. BMJ: British Medical Journal 317, no. 7170 (1998): 1446-9. [CrossRef]

Oliver, Mike. 'The Social Model of Disability: Thirty Years On'. Disability and Society 28, no. 7 (2013): 1024-6. [CrossRef]

O'Neill, Michel, and Paule Simard. 'Choosing Indicators to Evaluate Healthy Cities Projects: A Political Task?'. Health Promotion International 21, no. 2 (2006): 145-52. [CrossRef]

Ortolani, Chiara. 'The Importance of Neighbourhood for Urban Resilience'. Civil Engineering Research Journal 1, no. 3 (2017): 555562. [CrossRef]

Ostroff, Elaine. 'Universal Design: An Evolving Paradigm'. In Universal Design Handbook, edited by Wolfgang F. E. Preiser and Korydon H. Smith. New York: McGraw-Hill, 2011.

Park, Jiyoung, Jungwon Yoon, and Kwang-Hyun Kim. 'Critical Review of the Material Criteria of Building Sustainability Assessment Tools'. Sustainability 9, no. 2 (2017): 186. [CrossRef]

Peace, Sheila M. 'The Development of Residential and Nursing Home Care in the United Kingdom'. In End of Life in Care Homes: A Palliative Approach, edited by Jeanne Samson Katz and Sheila Peace, 15-42. Oxford: Oxford University Press, 2003.

Pfeiffer, David. 'The Conceptualization of Disability'. In Exploring Theories and Expanding Methodologies: Where We Are and Where We Need to Go, edited by Sharon N. Barnartt and Barbara M. Altman, 29-52. Bingley: Emerald, 2001. 
Philibert, Mathieu, Robert Pampalon, and Mark Daniel. 'Conceptual and Operational Considerations in Identifying Socioenvironmental Factors Associated with Disabiliy among Community-Dwelling Adults'. International Journal of Environmental Research and Public Health 12 (2015): 3814-34. [CrossRef]

Pilkington, Paul, Janet Ige, Daniel Black, and Emily Prestwood. The Impact of the Built Environment on Health: An Evidence Review: Initial Output of Upstream Project. Healthy City Design International, 2017.

Priestley, Mark, Lisa Waddington, and Carlotta Bessozi. 'New Priorities for Disability Research in Europe: Towards a User-Led Agenda'. Alter 4 (2010): 239-55. [CrossRef]

Project for Public Spaces and Metropolitan Planning Council. A Guide to Neighborhood Placemaking in Chicago, 2008. Accessed 23 August 2019. http://www.placemakingchicago.com/cmsfiles/ placemaking_guide.pdf.

Pugalis, Lee. 'The Evolutionary “Waves” of Place-Shaping: Pre, During and Post Recession'. Journal of Town and City Management 2, no. 3 (2011): 263-79.

Quinn, Gerard, Theresia Degener, Anna Bruce, Christine Burke, Joshua Castellino, Padraic Kenna, Ursula Kilkelly, and Shivaun Quinlivan. Human Rights and Disability, The Current Use and Future Potential of United Nations Human Rights Instruments in the Context of Disability. New York and Geneva: United Nations, 2002.

Realpe, Alba, and Louise M. Wallace. What is Co-Production? London: The Health Foundation, 2010.

Rollings, Kimberly A., Nancy M. Wells, and Gary W. Evan. 'Measuring Physical Neighbourhood Quality Related to Health'. Behavioral Sciences 5 (2015): 190-202. [CrossRef]

Rosenberg, Dori E., Deborah L. Huang, Shannon D. Simonovich, and Basia Belza. 'Outdoor Built Environment Barriers and Facilitators to Activity among Midlife and Older Adults with Mobility Disabilities'. The Gerontologist 53 (2012): 268-79. [CrossRef]

Rosso, Andrea L., Amy H. Auchincloss, and Yvonne L. Michael. 'The Urban Built Environment and Mobility in Older Adults: A Comprehensive Review'. Journal of Aging Research 2011 (2011): 816106. [CrossRef]

Saeidi, Sanaz, and Derya Oktay. 'Diversity for Better Quality of Community Life: Evaluations in Famagusta Neighbourhoods'. Procedia - Social and Behavioral Sciences 35 (2012): 495-504. [CrossRef]

Schindler, Sarah. 'Architectural Exclusion: Discrimination and Segregation through Physical Design of the Built Environment'. The Yale Law Journal 124 (2015): 1836-2201.

Schipperijn, Jasper, Jacqueline Kerr, Scott Duncan, Thomas Madsen, Charlotte Demant Klinker, and Jens Troelsen. 'Dynamic Accuracy of GPS Receivers for Use in Health Research: A Novel Method to Assess GPS Accuracy in Real-World Settings'. Frontiers in Public Health 2 (2014). [CrossRef]

Scotch, Richard K. 'Models of Disability and the Americans with Disabilities Act'. Berkeley Journal of Employment \& Labor Law 21, no. 1 (2000): 213-22. [CrossRef]

Sipe, Neil, Severine Mayere-Donehue, and Aysin Dedekorkut. 'Measuring Urban Form: A Comparative Analysis of South East Queensland and South Florida'. Paper presented at the World Planning Schools Congress 2011: Planning in an Era of Uncertainty and Transformation, Perth, WA, Australia, 4-8 July 2011.

Soder, Marten. 'Tensions, Perspectives and Themes in Disability Studies'. Scandinavian Journal of Disability Research 11, no. 2 (2009): 67-81. [CrossRef]

Soubra, Souheil, and Sophia Antipolis. Bridging the Gap between Building Information Modelling and Geospatial Information. Amsterdam: GeoBim, 2014.

Stainton, Tim. 'Intellectual Disability, Oppression and Difference'. In Countering Discrimination in Social Work, edited by Bogdan Lesnik, (original edition, 1998). London: Routledge, 2017.

Surface. Towards Access Standards: The Work of Local Access Groups in England and Wales. Manchester: Equality and Human Rights Commission, 2004.

Sutto-Long, Cat, Kristina Skov Aagaard, Zaana Howard, and Vito Tassone. Co-Design for Community Inclusion, 2016. Accessed 23 August 2019. https://www.nds.org.au/images/events/files/huddle_ report.pdf. 
Tappe, Karyn A, Karen Glanz, James F Sallis, Chuan Zhou, and Brian E Saelens. 'Children's Physical Activity and Parents' Perception of the neighborhood Environment: Neighborhood Impact on Kids Study'. International Journal of Behavioral Nutrition and Physical Activity 10, no. 39 (2013). [CrossRef]

Tilley, Sara, Chris Neale, Agnes Patuano, and Steve Cinderby. 'Older People's Experiences of Mobility and Mood in an Urban Environment: A Mixed Methods Approach Using Electroencephalography (EEG) and Interviews'. International Journal of Environmental Research and Public Health 14, no. 2 (2017): 151. [CrossRef]

Timperio, Anna, Robert W. Jeffery, David Crawford, Rebecca Roberts, Billie Giles-Corti, and Kylie Ball. 'Neighbourhood Physical Activity Environments and Adiposity in Children and Mothers: A Three-Year Longitudinal Study'. International Journal of Behavioral Nutrition and Physical Activity 7 (2010): 18. [CrossRef]

Tschoerner, Chelsea. 'A Governance Approach to Sustainable Mobility'. In Sustainable Mobility in Metropolitan Regions, edited by Gebhard Wulfhorst and Stefan Klug, 19-31. Wiesbaden: Springer, 2016.

Tudor, Christine. An Approach to Landscape Character Assessment. Accessed 23 August 2019. https://assets.publishing.service.gov.uk/government/uploads/system/uploads/attachment_data/file/ 691184/landscape-character-assessment.pdf.

UN (United Nations). 'Convention on the Rights of Persons with Disabilities - Articles'. 2006. Accessed 23 August 2019. https://www.un.org/development/desa/disabilities/convention-on-the-rights-ofpersons-with-disabilities/convention-on-the-rights-of-persons-with-disabilities-2.html.

UN (United Nations), Department of Economic and Social Affairs, Population Division. World Population Ageing, 2015. Accessed 23 August 2019. https://www.un.org/en/development/desa/population/ publications/pdf/ageing/WPA2015_Report.pdf.

UN Human Rights: Office of the High Commissioner. 'Convention on Rights of Persons with Disabilities'. Accessed 23 August 2019. http://www.ohchr.org/EN/HRBodies/CRPD/Pages/ ConventionRightsPersonsWithDisabilities.aspx.

United Nations, Settlements Programme (UN-Habitat). Building Sustainability Assessment and Benchmarking: An Introduction, 2017. Accessed 23 August 2019. http://www.iisbe.org/system/files/ private/Building\%20Sustainability\%20Assessment\%20and\%20Benchmarking.pdf.

United States, Department of Justice Civil Rights Division (USDoJ CRD), Information and Technical Assistance on the Americans with Disability Act (Enforcement). Accessed 23 August 2019. https://www.ada.gov/enforce_current.htm.

VicHealth. 'Arts and Social Connection'. Accessed 23 August 2019. https://www.vichealth.vic.gov.au/ our-work/arts-and-social-connection.

Vietnam Green Building Council. Accessed 23 August 2019. https://vgbc.vn/en/about-vgbc/.

Villanueva, Karen, Gavin Pereira, Matthew Knuiman, Fiona Bull, Lisa Wood, Hayley Christian, Sarah Foster, Bryan J. Boruff, Bridget Beesley, Sharyn Hickey, Sarah Joyce, Andrea Nathan, Dick Saarloos, and Billie Giles-Corti. 'The Impact of the Built Environment on Health across the Life Course: Design of a Cross-Sectional Data Linkage Study'. BMJ Open 3 (2013). [CrossRef]

Water Rating. Accessed 23 August 2019. http://www.waterrating.gov.au/about/standards.

WELL v2 Pilot. Accessed 23 August 2019. https://v2.wellcertified.com/v2.1/en/community/feature/13.

Welle, Ben, Qingnan Liu, Wei Li, Claudia Adriazola-Steil, Robin King, Claudio Sarmiento, and Marta Obelheiro. Cities Safer by Design: Guidance and Examples to Promote Traffic Safety through Urban and Street Design Version 1.0. Washington, DC: World Resources Institute, 2015.

West, Raelene. 'What Do We Mean by Support? The Receipt of Disability Services and Compensation for People with a Spinal Cord Injury (SCI) in Victoria'. PhD thesis, University of Melbourne, 2012.

WHO (World Health Organization), and United Nations Development Programme. 'Health in SDGs'. Paper presented at the 9th Global Conference on Health Promotion, Shanghai, China, 21-24 November 2016.

Whitfield, Marcella. 'Measuring the Performance of Sustainable Communities'. Strategic Planning for Energy and the Environment 36, no. 4 (2017): 41-77. 
Williams, Anthony, Michael J. Ostwald, and Hedda Haugen Askland. Creativity, Design and Education: Theories, Positions and Challenges. Sydney: Australian learning \& Teaching Council, 2010.

Wilson, Jeffrey S., Cheryl M. Kelly, Mario Schootman, Elizabeth A. Baker, Aniruddha Banerjee, Morgan Clennin, and Douglas K. Miller. 'Assessing the Built Environment Using Omnidirectional Imagery'. American Journal of Preventive Medicine 42, no. 2 (2012): 193-9. [CrossRef]

Windows Energy Rating Scheme. 'About WERS'. Accessed 23 August 2019. https://www.wers.net/ werscontent/about-wers.

Wolfensberger, Wolf. The Origin and Nature of Our Institutional Models. Washington, DC: President's Committee on Mental Retardation, 1969.

World Green Building Council. Accessed 23 August 2019. http://www.worldgbc.org/thecommitment.

Yigitcanlar, Tan, and Fatih Dur. 'Developing a Sustainability Assessment Model: The Sustainable Infrastructure, Land-Use, Environmental and Transport Model'. Sustainability 2 (2010): 321-40. [CrossRef] 